\title{
Main lepidopteran pest species from an eucalyptus plantation in Minas Gerais, Brazil
}

\author{
Teresinha V. Zanuncio ${ }^{1}$, José C. Zanuncio ${ }^{1, *}$, Fernando A. de Freitas ${ }^{2}$, Dirceu Pratissoli ${ }^{3}$, \\ Camilla A.Z. Sediyama ${ }^{2}$ \& Vanessa P. Maffia ${ }^{1}$ \\ 1 Departamento de Biologia Animal/BIOAGRO, Universidade Federal de Viçosa, 36571-000, Viçosa, State of Minas \\ Gerais, Brazil. *Author for correspondence; zanuncio@ufv.br \\ 2 Departamento de Fitotecnia, Universidade Federal de Viçosa, 36571-000, Viçosa, State of Minas Gerais, Brasil. \\ 3 Departamento de Fitotecnia, Universidade Federal do Espírito Santo, 29.500-000, Alegre, State of Espírito Santo, \\ Brasil.
}

Received 08-X-2002. Corrected 11-II-2004. Accepted 28-XI-2004.

\begin{abstract}
Lepidoptera species were monitored in a plantation of Eucalyptus grandis in the Municipality of Bom Despacho, State of Minas Gerais, Brazil from March 1987 to February 1992. A total of 547 species were collected and divided in: primary pests: 13; secondary pests: 20; species without defined importance to eucalyptus: 79; and non-identified species: 435. These four groups had a mean of 5231.29; 338.18; 438.16 and 2222.87 individuals with a total of 8229.87 individuals collected per trap. The number of species without defined importance to eucalyptus, and non-identified species, increased during the collecting period of five years while those of primary and secondary pests showed similar numbers in all years. The most collected primary pests Thyrinteina arnobia Stoll and Stenalcidia sp. (Geometridae) showed higher frequencies during the driest and coldest periods of the year, whereas Psorocampa denticulata Schaus (Notodontidae) was most frequent during periods of higher rainfall. Species of groups III and IV increased in diversity with eucalyptus age. This area has a high probability of outbreaks of eucalyptus defoliating caterpillars, especially T. arnobia. For this reason, lepidopteran pests should be monitored in this plantation during the driest and coldest periods of the year, when they can reach population peaks. Rev. Biol. Trop. 54(2): 553-560. Epub 2006 Jun 01.
\end{abstract}

Keywords: Eucalyptus sp., primary pests, Thyrinteina arnobia, diversity, conservation, Brazil.

Wood demand for energy and its increasing use for products and by-products which had been previously obtained from native forest have brought environmental consequences including reduction of forest cover in Brazil (Zanuncio et al. 1998a). Eucalyptus species which are native from Australia, Indonesia, Papua New Guinea and Philippines (Ohmart and Edwards 1991) are the main ones used in plantations for wood supply. This is because of their rapid growth, precocity and adaptation to many habitats (Iwakiri et al. 1999, Zanuncio et al. 2001) in monocultures (Zanuncio et al. 2000). Homogeneous plantations can favour more specialized insect pests because they are different from the original vegetation structure which determines spatial distribution of resources for herbivores (Zanuncio et al. 1998a). For this reason insects usually found at endemic levels on native plants of the Myrtaceae family are now damaging eucalyptus plantations in Brazil (Zanuncio et al. 2000). This has lead to the use of strategies of integrated management of these pests including the maintenance of strips of native vegetation which can increase heterogeneity and number of natural enemies of phytophagous species (Bragança et al. 1998a, 1998b, Zanuncio et al. 1998b). 
Defoliating insects are the main pests of eucalyptus plantations in Brazil (Zanuncio et al. 1993a) especially leaf cutting ants, and Coleoptera and Lepidoptera defoliators (Zanuncio et al. 2000). This last group is assuming more importance due to the amount of damage they do. The brown caterpillar Thyrinteina arnobia Stoll (Lepidoptera: Geometridae) in the main Lepidoptera pest of eucalyptus in Brazil.

Studies about population fluctuation are essential to establish programs of integrated management of insect pests (Zanuncio et al. 1994) which have being monitored in eucalyptus plantations in Brazil (Pereira et al. 2001). Since the majority of Lepidoptera defoliators of eucalyptus are night active the use of light traps represents the main sampling method for these insects in eucalyptus plantations in Brazil (Busoli et al. 1981).

Population studies allow us to characterize communities but it is also necessary to know their tendencies, cycles, seasonal variation and relative numeric abundance over time (Morales et al. 2000) because a population can be characterized through faunistic indexes such as those of frequency and constancy. The lack of predictive/quantitative analyses represents the main limitation of monitoring studies due to their short period of time (Guedes et al. 2000). On the other hand some authors have been developing studies considering population dynamics during longer periods for faunistic analyses (Zanuncio et al. 1998b, 2001, Guedes et al. 2000, Pereira et al. 2001).

The objective of this study was to determine population dynamics of Lepidoptera pests in an eucalyptus plantation in the Municipality of Bom Despacho, State of Minas Gerais, Brazil over five years. Information about potential damage of Lepidoptera species associated with eucalyptus, besides faunistic and constancy indexes and population fluctuation of main Lepidoptera defoliator pests and species with higher numbers of individuals were obtained.

\section{MATERIALS AND METHODS}

This study was developed in a plantation of Eucalyptus grandis in the Municipality of Bom Despacho, State of Minas Gerais, Brazil from March 1987 to February 1992. Lepidoptera species were collected biweekly with five light traps with black light (powered by 12 volt batteries) installed at $2 \mathrm{~m}$ height. A plastic bag with pieces of paper and a glass with ethyl acetate was fixed to the funnel of each trap with the aim of reducing morphological damage to insects collected (Zanuncio et al. 1998a).

Insects collected were conditioned in entomological blankets labeled with place, date of collection and they were sent to the laboratory of Forest Entomology at the "Universidade Federal de Viçosa (UFV)" where they were separated, counted, classified and, those in good conditions, mounted. The identification of these insects was based on the literature and by comparison with entomological collections of the UFV, "Universidade Federal do Paraná (UFPr)" and "Escola Superior de Agriculture 'Luiz of Queiroz' (ESALQ / USP)”.

Lepidoptera collected were divided in four groups according to their importance to eucalyptus plantations (Zanuncio et al. 1993a). Group I includes species considered primary pests; group II, species considered secondary pests because they have been occurring in limited outbreaks, associated or not to primary pests; group III, identified species without defined importance to eucalyptus culture and group IV, non identified species.

Frequency index (IF) for each primary pest specie was obtained with the formula: $\mathrm{IF}=$ $\mathrm{N} \times 100 / \mathrm{T}$, where: $\mathrm{IF}=$ frequency index $(\%)$; $\mathrm{N}=$ number of individuals per pest species; $\mathrm{T}=$ total number of primary Lepidoptera pests (Bodenheimer 1955, Dajoz 1973, Silveira Neto et al. 1976, Gallo et al. 2002).

Constancy of each primary pest species was determined with the formula: $\mathrm{C}=\mathrm{P} \times 100$ / 
$\mathrm{T}$, where $\mathrm{C}=$ constancy index $; \mathrm{P}=$ total number of collections with a specific pest species; $\mathrm{N}=$ total number of collections. Pest species were classified in the following categories based on constancy indexes (Bodenheimer 1955, Silveira Neto et al. 1976, Gallo et al. 2002): constant species $(\mathrm{X})=$ present in more than $50 \%$ of collections; accessory species $(\mathrm{Y})=$ present in $25 \%$ to $50 \%$ of collections and accidental species $(Z)=$ present in less than $25 \%$ of collections.

Faunistic analysis of Lepidoptera species was made with frequency and constancy indexes (Bodenheimer 1955, Silveira Neto et al. 1976, Gallo et al. 2002). Biweekly average of number of individuals of Lepidoptera primary and secondary pest species and of those with higher number of individuals, T. arnobia, Stenalcidia sp. (Geometridae) and Psorocampa denticulata Schaus (Notodontidae) was plotted on a logarithmic scale for the five years of collection.

\section{RESULTS}

A total of 547 Lepidoptera species were collected during these five years of monitoring, being (I) 13 primary pests, (II) 20 secondary pests, (III) 79 without defined importance to the eucalyptus culture and (IV) 435 non identified species (Table 1). These four groups presented 5231.29 ; 338.18; 438.16 and 2222.87 individuals, respectively, with a total of 8229.87 Lepidoptera individuals collected per trap during five years (Table 1). The pattern of total number of individuals collected was similar to that of primary pests (Fig. 1).
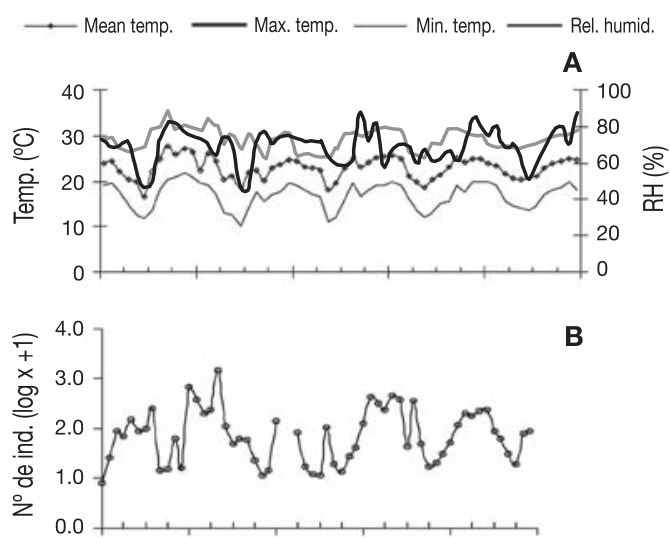

B
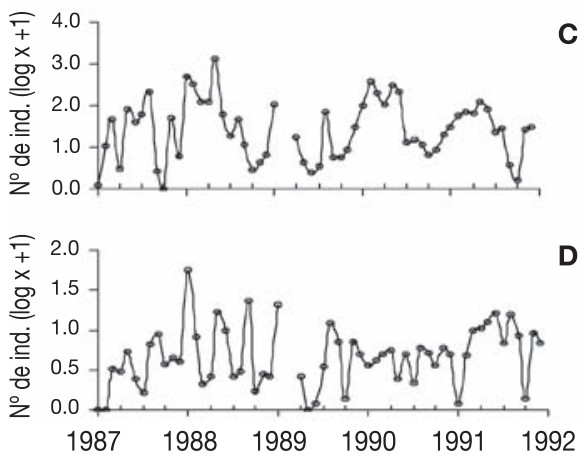

Fig. 1. Mean, maximum and minimum temperatures, relative humidity (A) and total number of individuals of Lepidoptera (B), of primary (C) and secondary (D) pests collected in the Municipality of Bom Despacho, State of Minas Gerais, Brazil. March 1987 to February 1992. Discontinued lines indicated that collections were not made in these dates.

TABLE 1

Mean number of species, individuals per trap and individuals per trap per species of Lepidoptera collected in the Municipality of Bom Despacho, State of Minas Gerais, Brazil. March 1987 to February 1992

\section{Groups}

(I) Primary pests

(II) Secondary Pests

(III) Species without defined importance

(IV) Unidentified species

Total
Species

13

20

79

435

547
Individuals/ trap

5231.29

338.18

438.16

2222.87

8229.87
Individuals/ trap/ species

402.41

16.91

5.55

5.11

15.05 
Group I presented highest number of individuals per trap per species (402.41), followed by groups II, III and IV with, respectively, $16.91 ; 5.55$ and 5.11 individuals per trap per species (Table 1).

Groups III and IV represented 32.33\% of total number of individuals collected with lowest number per trap per species. A low increment on number of species of groups I and II was found during these five years of collection in a different manner to that observed for groups III and IV mainly for this last one (Table 2).
T. arnobia, Stenalcidia sp. and P. denticulata were the most collected pest species with $2,324.78,1,901.35$ and 216.85 individuals per trap, respectively (Table 3 ). These three species represented $84.94 \%$ of the total number of individuals of primary pests. Out of 13 primary pests, T. arnobia, Stenalcidia sp., Oxydia vesulia Cramer (Geometridae), Sarsina violascens Herrich-Schaeffer (Lymantriidae) and Dirphia rosacordis Walker (Saturniidae) were constant species; Blera varana Schaus (Notodontidae), Eupseudosoma aberrans Schaus, Eupseudosoma involuta Sepp

TABLE 2

Number of Lepidoptera species of groups I, II, III e IV collected per year with light traps in the Municipality of Bom Despacho, State of Minas Gerais, Brazil. March 1987 to February 1992

\begin{tabular}{cccccc} 
Groups & \multicolumn{5}{c}{ Species } \\
I & $87-88$ & $88-89$ & $89-90$ & $90-91$ & $91-92$ \\
II & 10 & 12 & 10 & 11 & 13 \\
III & 10 & 16 & 15 & 14 & 15 \\
IV & 40 & 54 & 33 & 43 & 62 \\
& 178 & 210 & 129 & 133 & 255
\end{tabular}

TABLE 3

Species, families and individuals per trap (Ind.) and frequency (Freq.) and constancy (Const.) indexes for Lepidoptera primary pests collected with light traps in the Municipality of Bom Despacho, State of Minas Gerais, Brazil. March 1987 to February 1992

\begin{tabular}{lcccc}
\multicolumn{1}{c}{ Species } & Family & Ind. & Freq. (\%) & Const. \\
Thyrinteina arnobia Stoll & Geometridae & 2324.78 & 44.44 & $\mathrm{X}$ \\
Stenalcidia sp. & Geometridae & 1901.35 & 36.35 & $\mathrm{X}$ \\
Psorocampa denticulata Schaus & Notodontidae & 216.85 & 4.15 & $\mathrm{Y}$ \\
Oxydia vesulia Cramer & Geometridae & 173.58 & 3.31 & $\mathrm{X}$ \\
Dirphia rosacordis Walker & Saturniidae & 165.74 & 3.17 & $\mathrm{X}$ \\
Sarsina violascens Herrich-Schaeffer & Lymantriidae & 143.75 & 2.75 & $\mathrm{X}$ \\
Eupseudosoma aberrans Schaus & Arctiidae & 114.08 & 2.18 & $\mathrm{Y}$ \\
Eupseudosoma involuta Sepp & Arctiidae & 105.16 & 2.01 & $\mathrm{Y}$ \\
Blera varana Schaus & Notodontidae & 38.25 & 0.73 & $\mathrm{Y}$ \\
Apatelodes sericea Schaus & Eupterotidae & 37.95 & 0.73 & $\mathrm{Z}$ \\
Nystalea nyseus Cramer & Notodontidae & 4.60 & 0.08 & $\mathrm{Z}$ \\
Misogada blerura Schaus & Notodontidae & 4.40 & 0.08 & $\mathrm{Z}$ \\
Sabulodes caberata Guenée & Geometridae & 0.80 & 0.02 & $\mathrm{Z}$ \\
Total & & 5231.29 & 100.00 &
\end{tabular}


(Arctiidae) and P. denticulata were accessories; and the other ones were accidentals (Table 3 ).

T. arnobia presented higher population peaks during coldest and driest periods of the year with higher population between March and July (Fig. 2). This species represented higher number of individuals during the second, fourth and fifth years of collections. Stenalcidia sp. also represented higher proportion of the catch during the driest and coldest periods of the year and population peaks occurred between May and September (Fig. 2) but with a more regular pattern than that found for T. arnobia with lower number of individuals also in the third year. $P$. denticulata presented higher abundance of individuals during periods of higher temperature and relative humidity (Fig. 2) in a opposite way to that observed for T. arnobia and Stenalcidia sp.

\section{DISCUSSION}

Species of primary (group I) and secondary (group II) pests of eucalyptus represented $67.67 \%$ of total number of individuals collected. This shows the high adaptability and coexistence of these Lepidoptera pests with eucalyptus plantations in the region of Bom Despacho.

Number of individuals per species of groups I and II especially of group I and diversity of Lepidoptera species in this region showed lower values than that found by Zanuncio et al. (1998b, 2001), Guedes et al. (2000). This shows a lower recovery on the Lepidoptera fauna in eucalyptus crops in this region. More specialized herbivores are favored by higher quantity of food in these crops which associated to reduced pressure of natural enemies (Andrewartha and Birth 1984, Price 1984) can increase their damage to these plants. On the other hand these herbivores have more difficulties to find and to colonize their host plants in more heterogeneous environment where food is more scarce and survival and persistence of natural enemies are higher (Bragança et al. 1998a, 1998b, Zanuncio et al. 1998a).
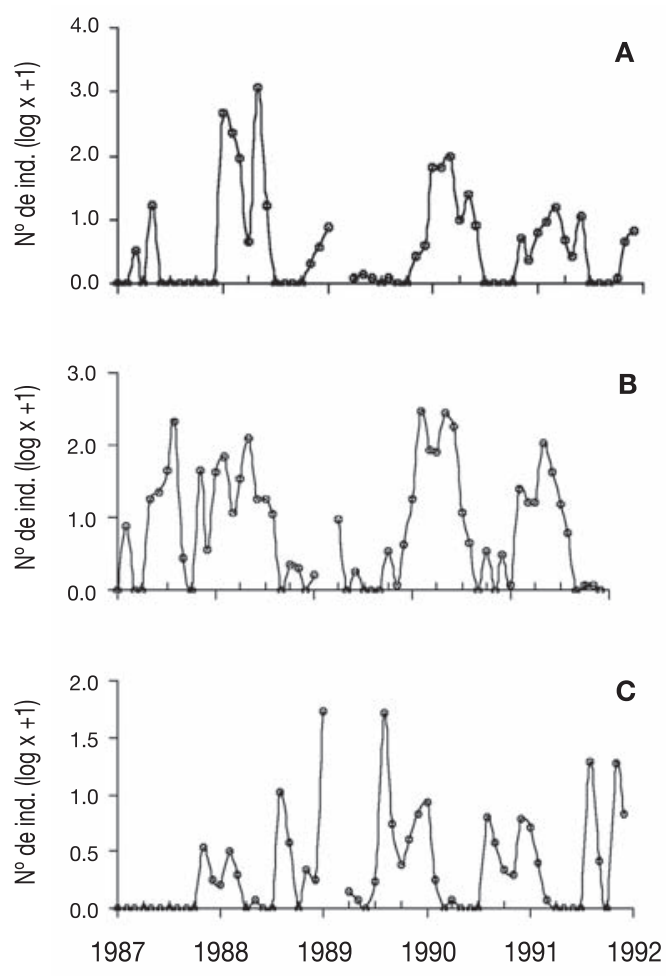

Fig. 2. Population fluctuation of Thyrinteina arnobia (Geometridae) (A), Stenalcidia sp. (Geometridae) (B) and Psorocampa denticulata (Notodontidae) (C) in the Municipality of Bom Despacho, State of Minas Gerais, Brazil. March 1987 to February 1992. Discontinued lines indicated that collections were not made in these dates.

The high number of individuals and of individuals per species of groups I and II suggests higher possibilities of outbreaks of these species in the region of Bom Despacho. However food supply do not represent the only factor responsible for outbreaks of Lepidoptera pests because unfavourable environmental conditions to plants can also favour population peaks of pest species (Elton 1975, Wallner 1987). Temporary distribution of species of groups I and II showed higher number of individuals during periods of lower temperature and relative humidity (Fig. 1) when plants can present stress mainly due to water deficit. This can reduce their defense mechanisms which can facilitate survival and concentration of pests in eucalyptus plantations during this time of the 
year. Besides, processes of plant defense and presence of digestibility reducers and of toxins to herbivores and alelochemical liberation for attraction of natural enemies are reduced in these conditions (Cavalcanti 1995).

Low number of individuals and of individuals per trap per species of groups III and IV indicates that these species do not feed on eucalyptus plants but they are associated to understorey plants or to those present on remaining strips or reserves of native vegetation (Zanuncio et al. 1998a, Pereira et al. 2001).

Low increment on number of species of groups I and II and higher numbers of those of groups III and IV during the five years of collection can be due to a progressive recovery of the ecosystem especially of the vegetation under eucalyptus plants. This can occur because cultural treatments are reduced with age increase of the plantation what might allow diversity of vegetation and Lepidoptera fauna to recover (Zanuncio et al. 1998a, 1998b, Pereira et al. 2001). This shows that silvicultural practices which preserve vegetation are important for maintenance of heterogeneity of Lepidoptera species and of their natural enemies (Bragança et al. 1998a, 1998b).

The high frequency of $T$. arnobia, Stenalcidia sp. and $P$. denticulata indicates that the region of Bom Despacho presents favourable ecological and climatic conditions for reproduction and establishment of these species. T. arnobia is considered the main Lepidoptera pest species of eucalyptus in Brazil and it presents irregular occurrence pattern. Lower number of individuals of this species was found during the first year in a similar way as recorded by Pereira et al. (2001) in the region of Três Marias, State of Minas Gerais, Brazil what can indicate that this species prefers older eucalyptus plants. Lowest number of individuals of T. arnobia and Stenalcidia sp. in the third year can be due to the impact of natural enemies especially predatory bugs because these organisms, naturally, increase their population in areas where pests have higher number of individuals and they can maintain this number at low levels for the next period (Barcelos et al. 1991). This shows the importance of management of populations of natural enemies including their rearing and liberation aiming to maintain pest populations below economic damage and to avoid the use of insecticides because pest species can develop resistance to constant applications of chemical products (Zanuncio et al. 1994, 1996, 1996-1997).

T. arnobia is considered the main defoliator Lepidoptera of eucalyptus in Brazil with economic damage to these plants (Zanuncio 1993 ) but $S$. grosica also present high voracity in plants of eucalypt. This shows the importance of monitoring both species aiming to reduce damage to these plants (Santos et al. 1998). T. arnobia and S. grosica were found during the whole period.

Largest abundance of $P$. denticulata during periods of higher temperature and relative humidity is the opposite to that observed for T. arnobia and Stenalcidia sp. This can be explained by the biology of this pest which pupates in the soil where it needs humidity for adult emergency (Zanuncio et al. 1993b). Caterpillars of $P$. denticulata also have high voracity on eucalyptus plants and this species has been reported at epidemic levels in several Municipalities of the State of Minas Gerais, Brazil. This has led to the development of programs to control and to monitor this pest and to reduce its damage (Zanuncio 1993). Caterpillars of this species were found defoliating eucalyptus plants specially in periods before and after its population peaks.

High abundance of T. arnobia, Stenalcidia sp. and $P$. denticulata shows the necessity of studying their population dynamics. It is important to determine their periods of higher abundance and to reduce costs with monitoring besides facilitating control decision and introduction of natural enemies. Such activities can maintain populations of these pest species below economic level and to reduce the use of curative measures in case of outbreaks.

This area presents risks of population outbreaks of Lepidoptera pests of eucalyptus especially $T$. arnobia, Stenalcidia sp. and $P$. denticulata due to a high number of individuals 
and species of groups I and II and to the low diversity of the Lepidoptera fauna in this region. Also the increment on number of species of groups III and IV indicates that the diversity of Lepidoptera species can increase with diversity of vegetation under eucalyptus trees and around such plantations.

\section{ACKOWLEDGMENTS}

To "Conselho NacionaldeDesenvolvimento Científico e Tecnológico (CNPq)", to "Coordenação de Aperfeiçoamento de Pessoal de Nível Superior (CAPES)" and to "Fundação de Amparo à Pesquisa do Estado de Minas Gerais (FAPEMIG)".

\section{RESUMEN}

De marzo de 1987 a febrero de 1992 se realizó un monitoreo con trampas luminosas en plantaciones de Eucalyptus grandis en Bom Despacho, Minas Gerais, Brasil. Se recolectaron 547 especies del orden Lepidoptera: plagas primarias: 13; plagas secundarias: 20; especies sin importancia definida para el cultivo de eucalipto: 79; y especies no identificadas: 435. Estos cuatro grupos tuvieron medias de 5231.29; 338,18; 438.16 y 2222.87 individuos por trampa respectivamente, para un total de 8229.87 lepidopteros recolectados por trampa. Durante los cinco años hubo un aumento del número de especies de los grupos III y IV. Las plagas primarias con mayor número de individuos fueron Thyrinteina arnobia Stoll y Stenalcidia sp. (Geometridae), con las mayores frecuencias para los meses más secos y fríos del año. Psorocampa denticulata Schaus (Notodontidae) fue más abundante en los periodos más lluviosos. La probabilidad de brotes de larvas desfoliadoras de eucalipto, principalmente T. arnobia, es alta en la región. Se recomienda hacer el monitoreo de lepidópteros plaga en los periodos más secos y fríos del año, cuando pueden presentar picos poblacionales.

Palabras clave: Eucalyptus sp., plagas primarias, Thyrinteina arnobia, diversidad, conservación, Brasil.

\section{REFERENCES}

Andrewartha, H.G. \& L.C. Birch. 1984. The ecological Web - More on the distribution and abundance of animals. University of Chicago, Chicago, Illinois, USA. 323 p.
Barcelos, J.A.V., J.C. Zanuncio, G.P. Santos \& F.P. Reis. 1991. Viabilidade da criação, em laboratório, de Podisus nigrolimbatus (Spinola, 1852) (Hemiptera: Pentatomidae) sobre duas dietas. Rev. Árv. 15: 316322.

Bodenheimer, R.S. 1955. Précis d' ecologie animale. Payot, Paris. 315 p.

Bragança, M.A.L., O. Souza \& J.C. Zanuncio. 1998a. Environmental heterogeneity as a strategy for pest management in Eucalyptus plantations. For. Ecol. Manag. 102: 9-12.

Bragança, M.A.L., J.C. Zanuncio, M.C. Picanço \& A.J. Laranjeiro. 1998b. Effects of environmental heterogeneity on Lepidoptera and Hymenoptera populations in Eucalyptus plantations in Brazil. For. Ecol. and Manag. 103: 287-292.

Busoli, A.C., F.M. Lara \& S.S. Neto. 1981. Flutuações populacionais de algumas pragas das famílias Pyralidae, Sphingidae, Arctiidae e Gelechiidae (Lepidoptera), na região de Jaboticabal, SP, e influência dos fatores meteorológicos. An. Soc. Entomol. Brasil. 10: 27-41.

Cavalcanti, M.G. 1995. Podisus nigrispinus (Dallas) (Heteroptera: Pentatomidae), Thyrinteina arnobia Stoll (Lepidoptera: Geometridae) e espécies de Eucalyptus: Interação entre os três níveis tróficos. M.S. Thesis, Universidade Federal de Viçosa, Viçosa, Brazil. 67 p.

Dajoz, R. 1973. Ecologia Geral. Vozes, Petrópolis, Brazil. $472 \mathrm{p}$.

Elton, C.S. 1975. Conservation and the low population density of invertebrates inside neotropical rain forest. Biol. Conserv. 7: 3-15.

Gallo, D., O. Nakano, S. Silveira Neto, R.P.L. Carvalho, G.C. Baptista, E. Berti Filho, J.R.P. Parra, R.A. Zucchi, S.B. Alves, J.D. Vendramin, L.C. Marchini, J.R.S. Lopes \& C. Omoto. 2002. Entomologia agrícola. FEALQ, Piracicaba, Brazil. 920 p.

Guedes, R.N.C., T.V. Zanuncio, J.C. Zanuncio \& A.G.B. Medeiros. 2000. Species richness and fluctuation of defoliator Lepidoptera populations in Brazilian plantations of Eucalyptus grandis as affected by plant age and weather factors. For. Ecol. Manage. 137: $179-184$.

Iwakiri, S., S.J. Pereira \& S. Nisgoski. 1999. Avaliação da qualidade de clonagem em compensados de Eucalyptus cloeziana e Eucalyptus robusta. Flor. Amb. 6: 45-50.

Morales, N.E., J.C. Zanuncio, D. Pratissoli \& A.S. Fabres. 2000. Fluctuación poblacional de Scolytidae 
(Coleoptera) en zonas reforestadas con Eucalyptus grandis (Myrtaceae) en Minas Gerais, Brasil. Rev. Biol. Trop. 48: 101-107.

Ohmart, C.P. \& P.B. Edwards. 1991. Insect herbivory on Eucalyptus. Ann. Rev. Entomol. 36: 637-657.

Pereira, J.M.M., T.V. Zanuncio, J.C. Zanuncio \& D. Pratissoli. 2001. Lepidoptera pests collected in Eucalyptus urophylla plantations during five years in Três Marias, State of Minas Gerais, Brazil. Rev. Biol. Trop. 49: 997-1006.

Price, P.W. 1984. Insect Ecology. Wiley, New York. 607 p.

Santos, G.P., T.V. Zanuncio, J.C. Zanuncio \& A.G.B. Medeiros.1998. Biologia de Stenalcidia grosica Schaus (Lepidoptera, Geometridae) em folhas de Eucalyptus urophylla e aspectos de sua ocorrência e controle. Rev. Bras. Entomol. 41: 229-232.

Silveira Neto, S., O. Nakano, D. Barbin \& N.A. Vila Nova. 1976. Manual de Ecologia dos Insetos. Ed. Agronômica Ceres, São Paulo, Brazil. 419 p.

Wallner, W.E. 1987. Factors affecting insect population dynamics: differences between outbreak and non-outbreak species. Ann. Rev. Entomol. 32: 317-340.

Zanuncio, J.C. (Coord.). 1993. Lepidoptera desfolhadores de eucalipto: Biologia, Ecologia e Controle, IPEF/ SIF, Viçosa, Brazil. 140 p.

Zanuncio, J.C., J.B. Alves, G.P. Santos \& W.O. Campos. 1993a. Levantamento e flutuação populacional de lepidópteros associados à eucaliptocultura: VI - Região de Belo Oriente, Minas Gerais. Pesq. Agropec. Brasileira 28: 1121-1127.

Zanuncio, J.C., G.P. Santos, T.V. Zanuncio \& M.R.B. Smith. 1993b. Levantamento e flutuação populacional de lepidópteros associados à eucaliptocultura: VII
- Região de Belo Oriente, Minas Gerais, junho de 1988 a maio de 1989. Científica 21: 361-371.

Zanuncio, J.C., E.C. Nascimento, J.F. Garcia \& T.V. Zanuncio 1994. Major lepidopterous defoliators of eucalypt in southeast Brazil. For. Ecol. Manage. 45: 53-63.

Zanuncio, J.C, J.L.D. Saavedra, H.N. Oliveira, D. Degheele \& P. De Clercq. 1996. Development of the predatory stinkbug Brontocoris tabidus (Signoret) (Heteroptera: Pentatomidae) on different proportions of an artificial diet and pupae of Tenebrio molitor L. (Coleoptera: Tenebrionidae). Bioc. Sci. Technol. 6: 619-625.

Zanuncio, J.C., J.L.D. Saavedra, T.V. Zanuncio \& G.P. Santos. 1996-1997. Incremento en el peso de ninfas y adultos de Podisus nigrispinus (Heteroptera: Pentatomidae) alimentados con dos tipos de larvas. Rev. Biol. Trop. 45: 241-245.

Zanuncio, J.C., J.A. Mezzomo, R.N.C. Guedes \& A.C. Oliveira. 1998a. Influence of strips of native vegetation on Lepidoptera associated with Eucalyptus cloeziana in Brazil. For. Ecol. Manage. 108: 85-90.

Zanuncio, J.C., T.V. Zanuncio, E.T. Lopes \& F.S. Ramalho. 2000. Temporal variations of Lepidoptera collected in an Eucalyptus plantation in the State of Goiás, Brazil. Neth. J. Zool. 50: 435-443.

Zanuncio, J.C., R.N.C. Guedes, T.V. Zanuncio \& A.S. Fabres. 2001. Species richness and abundance of defoliating Lepidoptera associated with Eucalyptus grandis in Brazil and their response to plant age. Aust. Ecol. 26: 582-589.

Zanuncio, T.V., J.C. Zanuncio, M.M.M. Miranda \& A.G.B. Medeiros. 1998b. Effect of plantation age on diversity and population fluctuation of Lepidoptera collected in Eucalyptus plantations in Brazil. For. Ecol. Manage. 108: 91-98. 